\title{
Interpretation of Manchu Traditional Space Decoration in Inn Environment Design—Space Design of Sun Inn
}

\author{
Bowen Yin, Ting Zhang \\ Jiangxi Normal University, Nanchang 330022, Jiangxi Province, China
}

\begin{abstract}
In the space design of solar inn, we should grasp the aesthetic fatigue of modern tourists to the common commercial hotel and build a hotel with the theme of national culture. Through on-the-spot investigation of the architectural culture characteristics of the Manchu nationality in Northeast China, the characteristics of the architectural culture of the Manchu nationality in Northeast China are analyzedThe study of folk architecture inherits and develops under the background of the development of the new era, so that the national cultural architecture can be better innovated, especially in the area similar to the Manchu folk culture in northeast China.
\end{abstract}

Keywords: Hotel Space; The Design; National Culture

\section{Overview of Manchu traditional space decoration}

\subsection{Manchu pattern art decoration}

The Manchu people do not accept the traditional culture passively, but actively integrate it with the essence and the dross. The pattern culture is an organic part of the traditional culture. Therefore, the art decoration of the Manchu pattern is also the inheritance and development of the traditional culture, which is the product of the development of the Manchu culture. These elements of Manchu culture decoration will be applied in the soft decoration design of the Sun Inn, such as bed ware murals and furniture.

The Manchus believe in the language and the "animism" of the Shamanism. The worship of language makes it form a unique way of expressing folk ideas. However, "animism" is shamanism's worship of gods, human spirits and material spirits, and it is a totem transformation mode from plane to three-dimensional, from three-dimensional to space, and from space to behavior. In this mode, from the plane to the three-dimensional, from the visual point of view to observe the color law of traditional patterns; From the threedimensional to the space, it is because the three-dimensional representation of manchu is reflected in the architectural expression, forming an illusory space, thus giving birth to faith. From space to behavior, it is mainly represented by ritual forms of praying for blessings and children of manchu. In this process, a unique Manchu culture emerged.

\subsection{Decoration of Manchu cultural elements}

Most of the decoration elements of Manchu culture come from Shamanism which is believed by Manchu people, so shamanism is related to Manchu culture.

Cultural decorative elements are of great influence. Since the manchu people live in the north of China, shamanism began in the prosperous period of the primitive matriarchal society in China, so it is an inevitable choice for the Manchu people to believe in Shamanism. Shaman is called the intermediary between man and God, who can tell man the will of God. Shamanism has special religious activities and rituals. It USES a large number of dharma implements and paints various exquisite patterns on them with rich colors, which is of certain artistic value. A large number of patterns of animals and plants were used in various ritual implements and religious activities, which were later reflected in the traditional paper-cut culture, manchu hand-embroidery culture, furniture, architectural decoration culture and so on. White flag, white flag, red flag, red flag, blue flag, blue flag. In the traditional Manchu family, the color of paper-cut on the ancestral board of the western wall inside the house can be used to judge the flag of the family members. Due to the influence of The Han culture, the Manchu people respect yellow as noble in color, and they prefer white more than red.

In modern decoration, to do the ancient and modern combination of modern technology to replicate the manchu ancient decorative hanging ceiling and sunk panel is difficult, and because of the housing structure, immutable factors such as geographical position, the condole top of modern design has been simplified, so if you want to highlight the manchu culture, want to combine the

Copyright (C) 2020 Bowen Yin et al.

doi: $10.18282 / 1-$ e.v9i3.1582

This is an open-access article distributed under the terms of the Creative Commons Attribution Non-Commercial License

(http://creativecommons.org/licenses/by-nc/4.0/), which permits unrestricted non-commercial use, distribution, and reproduction in any medium, provided the original work is properly cited. 
manchu traditional decoration on hard outfit at the same time to carry on the elaboration, simplify, mainly in soft outfit decoration aspects, such as festival inn overall can put a paper-cut window grilles, indoors textiles on the manchu traditional embroidery, auspicious pattern combined with embroidery, above all, not only in the sun inn soft outfit design, applying the manchu culture elements in the design of the inn, also on hard outfit design as far as possible the reduction of the manchu culture, has reached the "sun inn" inherit traditional culture, promote the purpose of the manchu culture.

\section{The application of Manchu traditional space decoration in the design of inn space}

\subsection{Design practice of Manchu traditional space}

The inn adopts the original structure of only one floor, which not only accords with the characteristics of "Manchu" housing, but also can adjust the original family type according to the design requirements. The inn is divided into three parts Front, middle and back - reception area, leisure area, and accommodation area. This clear functional division not only makes no noise, but also has more space to highlight the "Manchu culture". The front desk of the inn is a little smaller, which is also different from most fast chain hotels. The front desk is large and the reception is small, which greatly reduces the pressure of tourists. In the front area, there are two "ten-word Kang" rooms, which are mainly for friends' parties, groups and other groups, and can accommodate up to 10 percent.

Inn overall layout is connected fully, across the front desk reception area is an outdoor open recreational space, this area is two stairs, the goal is to clear regional division, make whole space in rhythmic, visitors can relax here in your free time, summer sun and winter snow, the overall design of manchu culture inn relative to heavy, so the space design, the color heavy space sense of increased permeability and expansiveness.

Passing through the leisure area is the accommodation area for tourists to rest. Because the front desk is relatively far from the accommodation area, in order to provide consumers with more convenient services, a service reception desk is also set up in this space. In the accommodation area and recreational area and dining tables, is to avoid some consumers don't want to in outdoor activities and natural factors, the design has greatly increased the consumers living experience, manchu tea culture also has a long history, in the region can drink tea, taste some manchu small cakes, adds a little to play time. Due to location - Ye He that pull the for tourists is the manchu culture of the ancient city of interest, corporate party building, and friends to get-together and Tours, for consumers, only interest in manchu culture lovers will be permanent, other consumers are lodging is not more than five days (Ye He that pulled the old city area is not large, tourists stay less time), so the hotel can accommodate 40 people at most, although not quite, but should do fine beauty, service in place, the manchu culture outstanding characteristics, natural word of mouth will be better, only a steady stream of praise of consumers, to achieve the goal of the manchu culture.

The soft outfit of the hall goes up, use sofa of large real wood, main hall places stone lion, consumer can have strong visual walit at the first glance, first impression can be very "special". The pillow of sofa is most often used traditional manchu decoration color red, blue, yellow, silken face texture is very gorgeous, with a white and green landscape painting after the desk with the case of short ark, the combination of the overall, will give visitors the feeling of a kind of solemn, but appear a layout environment, also won't let a person feel nervous, plus "rest" and the overall decoration and soft decoration of the guest rooms of the "Sun Inn" are very manchu. The color of double bed room is given priority to with white and log color, background wall is a simple log for Mosaic on a white wall, condole top is in the original painted mat style of art on the wall, plus logs, the background wall and ceiling mutual echo, two wooden grid fake doors is to play the role of the middle transition, make integral space is simple but do not break delicate, bed and TV ark are real wood is qualitative, this also is the core of manchu furniture material, in the soft outfit to go to bed flag is blue embroidered silk, embroidery is the manchu intangible cultural heritage, so the inn on the soft outfit USES the traditional embroidery handicraft, also is to let consumers understand the manchu culture in detail. Because the overall space design reflects the Manchu style to a large extent, but the color is a little monotonous, so the bedside hanging picture chooses more modern green plants, the space is more vibrant

\section{References}

$1 \mathrm{Xu}$ Ya, Xie Le. Research on B\&B space design under the background of regional culture [J]. Building materials and decoration, 2017.

2 Yang Maochuan, Wang Yifei. Creating artistic conception-The application of Chinese regional culture in contemporary hotel design [J], Furniture and Interior Decoration, 2006.

3 Li Yantian. Indoor and outdoor space design based on ethnic minority regional background [D], Kunming University of Science and Technology, 2014.

4 Xue Jian, Su Hua. Decoration Design and Construction Manual. China Construction Industry Press, 2004.11.

5 Zhao Yujing. Jiamusi Hezhe style theme hotel design research [J]. Economic Research Guide, 2013. 